\title{
Use of the bomb radiocarbon chronometer to determine age of southern bluefin tuna Thunnus maccoyii
}

\author{
John M. Kalish ${ }^{1, *}$, Justine M. Johnston ${ }^{1}$, John S. Gunn ${ }^{2}$, Naomi P. Clear ${ }^{2}$ \\ ${ }^{1}$ Division of Botany and Zoology, The Australian National University, Canberra, ACT 0200, Australia \\ ${ }^{2}$ CSIRO Marine Laboratories, GPO Box 1538, Hobart, Tasmania 7001, Australia
}

\begin{abstract}
The growing otoliths of fish incorporate radiocarbon in concentrations that are equivalent to that found in ambient seawater dissolved inorganic carbon. Therefore, pulses of anthropogenic radiocarbon produced by the atmospheric detonation of nuclear weapons can ultimately be detected in otohths. This study estimates the age of large southern bluefin tuna Thunnus maccoyii using an age estimation procedure based on the determination of levels of bomb-derived radiocarbon in their otoliths. Radiocarbon data from selected regions of southern bluefin tuna otoliths indicate that this species may reach ages in excess of 30 yr Furthermore, individuals that approach the asymptotic length are likely to be $20 \mathrm{yr}$ of age or older. The data agree generally with accepted models of southern bluefin growth, but show that these fish live longer than was believed previously. Comparisons between otolith section and bomb radiocarbon age estimates indicate that reading otolith sections is an effective method to estimate the age of larger southern bluefin. The presence of a significant number of individuals greater than 20 yr of age in the southern bluefin population may alter estimates of natural mortality rates currently used in Virtual Population Analysis models for stock assessment of this species.
\end{abstract}

KEY WORDS: Age validation Bomb radiocarbon chronometer - Carbon - Otoliths Radiocarbon . Southern bluefin tuna. Thunnus maccoyii

\section{INTRODUCTION}

Southern bluefin tuna Thunnus maccoyii is a highly migratory species that is found throughout the Southern Ocean north of about $60^{\circ} \mathrm{S}$ latitude. Southern bluefin is exploited by fishers from Australia, Japan, New Zealand, Indonesia, Taiwan, and Korea and it is the most valuable commercial finfish species in Australia with the annual Australian catch valued at more than Australian $\$ 80$ million (Kailola et al. 1993). Catch rates for southern bluefin have decreased dramatically in the last decade, presumably due to increased fishing pressure on the resource, associated with its increased value (Caton et al. 1990). International management of southern bluefin has been placed under the juris-

•E-mail: john.kalish@anu.edu.au diction of the Convention for the Conservation of Southern Bluefin Tuna (CCSBT), a trilateral convention that includes Australia, Japan, and New Zealand as its members. The CCSBT has indicated that age estimation of southern bluefin is a high priority research area (Anonymous 1994). Furthermore, the lack of validated catch-at-age data for the exploited population has introduced significant uncertainty into the Virtual Population Analysis that is the primary stock assessment tool used by the CCSBT.

Age estimation for the larger tunas including southern bluefin and northern bluefin Thunnus thynnus is problematic due to difficulties involved in the interpretation of marks on hard parts, such as otoliths and vertebrae (Hurley \& Isles 1983, Prince \& Pulos 1983, Prince et al. 1985, Thorogood 1987). Furthermore, logistical problems associated with the mobility and longevity of these species make tagging studies and, 
concomitantly, the validation (sensu Kalish et al. 1995) of a 'preferred' age estimation procedure both difficult and costly. Despite the complications associated with age estimation and the related validation for the larger Thunnus spp., these areas of research have a high priority in many nations that have significant fisheries for these species. In Australia research related to age estimation for southern bluefin includes a mark-recapture study using strontium chloride to mark calcified tissues (N. P. Clear, J. S. Gunn \& A. J. Rees unpubl.), investigation of conventional age estimation methods based on otoliths and vertebrae (Gunn et al. 1995), and the application of bomb radiocarbon measured in otoliths to age determination and validation (this study).

Although obvious zones are present in the otoliths and vertebrae of southern bluefin of all sizes (Gunn et al. 1995), and annual bands have been validated in the otoliths of fish up to $6+\mathrm{yr}[133 \mathrm{~cm}$ fork length (FL); Clear et al. unpubl.], there are still problems with the interpretation of zones from calcified tissues of larger and presumably older fish. In larger southern bluefin, discrepancies in the number of presumed annual increments counted in otoliths and vertebrae have lead to uncertainty over which, if either, provides a true estimate of age for mature fish. An additional complication is the lack of known age individuals and the rarity of tagged and returned fish with long periods at liberty $(>10 \mathrm{yr}$ ). Similar problems exist for age estimation of Atlantic bluefin tuna Thunnus thynnus (Lee \& Prince 1995). Until recently, stock assessment of southern bluefin was carried out under the assumption that these fish can be up to 20 yr of age (Collette \& Nauen 1983, Majkowski \& Hampton 1983, Caton et al. 1990); however, the only direct evidence for this came from 1 tag recovery $20 \mathrm{yr}$ after release of a $1 \mathrm{yr}$ old bluefin (CSIRO unpubl. data).

Determination of southern bluefin longevity and validation of age estimation methods for larger individuals is required in order to increase the reliability of stock assessments for this species. Zone counts in otoliths (Gunn et al. 1995) have suggested ages well in excess of the previously accepted maximum age of $20 \mathrm{yr}$, but in the absence of tag-recapture data there has been little chance of validating these estimates.

The bomb radiocarbon chronometer (Kalish 1993, $1995 \mathrm{a}, \mathrm{b})$ provides an alternative method to tagrecapture studies. The bomb radiocarbon chronometer can be used to estimate the age of individual fish and the technique is well-suited to estimating the age of southern bluefin tuna. Because there is no accepted 'routine' method for age estimation of larger southern bluefin tuna, direct estimation of age on the basis of the bomb radiocarbon chronometer presents a viable alternative to test assumptions regarding southern bluefin longevity. Southern bluefin are suited to age estimation using bomb radiocarbon due to the presumed longevity of the species and the likelihood that individuals in the present population were spawned during the bomb-related increase in radiocarbon in the atmosphere and ocean (Kalish 1993).

\section{MATERIALS AND METHODS}

Southern bluefin otoliths (sagittae) were selected from otolith archives maintained at the CSIRO Marine Laboratories (Hobart, Tasmania, Australia). A single otolith from each pair was selected for analysis, with the other otolith, when available, being retained for studies of routine age estimation procedures. The majority of otoliths selected were from large individuals as these fish are likely to be more suitable for age estimation on the basis of bomb radiocarbon due to their presumed birth date. Otoliths were obtained from large fish caught off southeast Tasmania and in the Java Sea between 1988 and 1994. Otoliths from 2 southern bluefin that were both 1 yr old $(55 \mathrm{~cm} F L$ ) were also selected to assist with calibration and to provide an indication of the decrease in ocean radiocarbon since 1980 . The small fish were caught off the southwest coast of Western Australia in 1985 and 1993. In this study, calibration refers to the process of establishing a relationship between surface ocean radiocarbon levels in a region and time (Kalish 1995b).

Otoliths were weighed dry and then prepared for radiocarbon and stable carbon isotope analysis. The earliest formed portions of individual otoliths was isolated with a fine, high speed drill. This was achieved by 'sculpting', from the larger otolith, an otolith that was representative of a southern bluefin less than $1 \mathrm{yr}$ of age. During the sculpting process the position of 'landmarks' such as the otolith core and zones associated with the presumed first annual increment were monitored frequently. This ensured that the sculpted otolith contained material only deposited during the early life of the fish. The final product was a single piece of otolith aragonite (Fig. 1). Sample weights ranged from about 13 to $24 \mathrm{mg}$. Otolith carbonate was converted to $\mathrm{CO}_{2}$ by reaction in vacuo with $100 \%$ phosphoric acid. An aliquot of the $\mathrm{CO}_{2}$ was used to determine $\delta^{13} \mathrm{C}$ for each sample and the remaining $\mathrm{CO}_{2}$ was converted to graphite (Lowe \& Judd 1987) for analysis of radiocarbon. Radiocarbon levels in each sample were determined by accelerator mass spectrometry (AMS) at the Institute of Geological and Nuclear Sciences, Lower Hutt, New Zealand (Wallace et al. 1987). Radiocarbon values are reported as $\Delta{ }^{14} \mathrm{C}$, which is the age-and fractionation-corrected per mil deviation from the activity of 19 th century wood (Stuiver \& Polach 1977). Radiocarbon determinations 

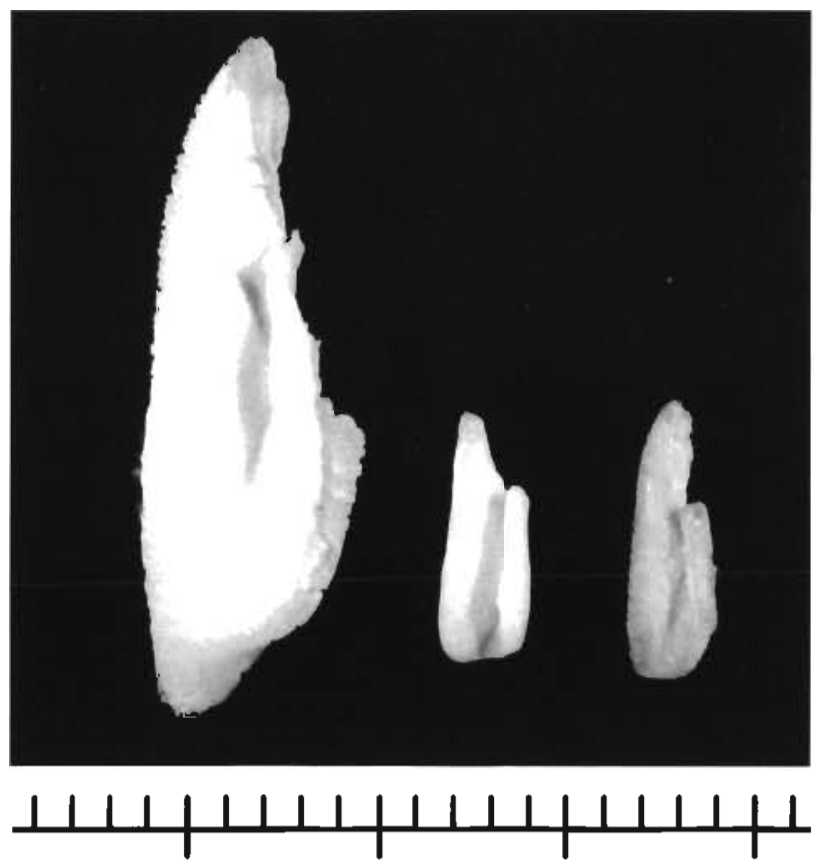

Fig. 1 Thunnus maccoyii. Comparison among, from left to right: whole sagitta $(219 \mathrm{mg})$ from $190 \mathrm{~cm}$ southern bluefin, sculpted sagitta $(18.6 \mathrm{mg})$ from $190 \mathrm{~cm}$ southern bluefin, whole sagitta $(14.2 \mathrm{mg})$ from $55 \mathrm{~cm}$ southern bluefin. Scale bar divisions $=1 \mathrm{~mm}$

were made via the NBS oxalic acid standard in conjunction with the Australian National University sucrose standard. Reported errors for the radiocarbon data are 1 standard deviation. Radiocarbon errors include both counting errors and laboratory random errors.

There are few radiocarbon data available that are suitable for the temporal calibration of radiocarbon data obtained from the earliest formed portions of southern bluefin tuna otoliths. This portion of the otolith is presumed to be deposited in the tropical and subtropical Indian Ocean, specifically in the region of the Java Sea and southeast Indian Ocean. Radiocarbon data were selected from both the pre- and post-nuclear testing GEOSECS (Geochemical Ocean Section Study) expeditions to the Indian Ocean (Bien et al. 1965, Stuiver \& Ostlund 1983), studies of corals from CocosKeeling Island (northeastern Indian Ocean; Toggweiler et al. 1991) (Table 1), and the otoliths of two $55 \mathrm{~cm}$ southern bluefin tuna that were both 1 yr (Table 2) old based on previous studies of southern bluefin age and growth (Gunn et al. 1995). These data were used to model the bomb-related increase in Indian Ocean radiocarbon during the 1960 s and 1970 s.

For zone counts, otoliths were embedded in polyester resin and sectioned with a low-speed diamond saw. Three parallel replicate sections were taken in the dorso-ventral plane (transverse), 1 anterior to the primordium, 1 through the primordium, and 1 posterior to it. Each section was then mounted on glass rounds and polished to thicknesses of 0.4 to $0.6 \mathrm{~mm}$ using 600 grade wet-dry paper

Age was estimated from otolith sections by a reader that had read more than 1000 southern bluefin otolith sections (N.P.C.). These age estimates were compared with age estimates derived from otolith radiocarbon data.

\section{RESULTS}

Birth date estimates for individual tuna were determined directly from the otolith radiocarbon data. A second order polynomial function that describes the bomb-related increase in $\triangle^{14} \mathrm{C}$ in the eastern Indian Ocean was established from a combination of the GEOSECS data, the Cocos-Keeling coral data, and the 2 small southern bluefin of known age (birth dates 1984 and 1992). Pre-bomb $\Delta^{14} \mathrm{C}$ measured from sea-

Table 1 Measurements of $\Delta^{14} \mathrm{C}$ made on tropical Indian Ocean surface water samples or corals from latitudes comparable to locations of juvenile Thunnus maccoyii otolith deposition. DIC: dissolved inorganic carbon

\begin{tabular}{|lclccc|}
\hline Latitude & Longitude & Sample type & Sample date & $\Delta^{14} \mathrm{C}(\%)$ & Reference \\
\hline $12^{\circ} \mathrm{S}$ & $97^{\circ} \mathrm{E}$ & Hermatypic coral & July 1953 & -30 & Toggweiler et al. (1991) \\
$12^{\circ} \mathrm{S}$ & $97^{\circ} \mathrm{E}$ & Hermatypic coral & July 1970 & 118 & Toggweiler et al. (1991) \\
$12^{\circ} \mathrm{S}$ & $97^{\circ} \mathrm{E}$ & Hermatypic coral & July 1972 & 129 & Toggweiler et al. (1991) \\
$12^{\circ} \mathrm{S}$ & $97^{\circ} \mathrm{E}$ & Hermatypic coral & July 1973 & 130 & Toggweiler et al. (1991) \\
$12^{\circ} \mathrm{S}$ & $97^{\circ} \mathrm{E}$ & Hermatypic coral & July 1974 & 134 & Toggweiler et al. (1991) \\
$12^{\circ} \mathrm{S}$ & $97^{\circ} \mathrm{E}$ & Hermatypic coral & July 1976 & 121 & Toggweiler et al. (1991) \\
$10^{\circ} 31^{\prime} \mathrm{S}$ & $105^{\circ} 34^{\prime} \mathrm{E}$ & Seawater DIC & 19 Oct 1960 & -16 & Bien et al. (1965) \\
$18^{\circ} 49^{\prime} \mathrm{S}$ & $88^{\circ} 33^{\prime} \mathrm{E}$ & Seawater DIC & 27 Nov 1960 & -7 & Bien et al. (1965) \\
$36^{\circ} 18^{\prime} \mathrm{S}$ & $98^{\circ} 41^{\prime} \mathrm{E}$ & Seawater DIC & 29 Dec 1960 & -25 & Bien et al. (1965) \\
$33^{\circ} 14^{\prime} \mathrm{S}$ & $108^{\circ} 45^{\prime} \mathrm{E}$ & Seawater DIC & 1 Jan 1961 & -15 & Bien et al. (1965) \\
$34^{\circ} 11^{\prime} \mathrm{S}$ & $105^{\circ} 49^{\prime} \mathrm{E}$ & Seawater DIC & 25 Nov 1962 & 20 & Bien et al. (1965) \\
$29^{\circ} 15^{\prime} \mathrm{S}$ & $109^{\circ} 58^{\prime} \mathrm{E}$ & Seawater DIC & $8 \mathrm{Mar} 1978$ & 140 & Stuiver \& Ostlund (1983) \\
\hline
\end{tabular}


Table 2. Thunnus maccoyin: fish and otolith data. Sample weights indicate the weight of otolith material separated for individual analyses of stable carbon and radiocarbon and are representative of less than the first year of otolith growth for an individual fish The birth date was determined as discussed in the text. The age is the date caught minus the buth date determined from the radiocarbon data

\begin{tabular}{|c|c|c|c|c|c|c|c|c|c|}
\hline $\begin{array}{l}\text { Sample } \\
\text { no. }\end{array}$ & $\begin{array}{l}\text { Date } \\
\text { caught }\end{array}$ & $\begin{array}{l}\text { Fork } \\
\text { length } \\
(\mathrm{cm})\end{array}$ & $\begin{array}{c}\text { Otoluth } \\
\text { wt } \\
\text { (g) }\end{array}$ & $\begin{array}{c}\text { Sample } \\
w t \\
(\mathrm{mg})\end{array}$ & $\begin{array}{c}\delta^{13} \mathrm{C} \\
(\%, \mathrm{PDB})\end{array}$ & $\begin{array}{l}\Delta^{1+C} \mathrm{C} \\
(\%)\end{array}$ & $\begin{array}{c}\text { Birth } \\
\text { date } \\
(\mathrm{yr}, \mathrm{AD})\end{array}$ & $\begin{array}{l}\text { Age } \\
\text { (yr) }\end{array}$ & $\begin{array}{c}\text { Otolith } \\
\text { section age } \\
\text { (birth date) }\end{array}$ \\
\hline 190 & 26 Nov 1988 & 195 & 0.1768 & 19.7 & -6.49 & $29.3 \pm 8.7$ & 1963 & 25 & $25(1963)$ \\
\hline 195 & $2 \operatorname{Dec} 1988$ & 190 & 0.1802 & 17.6 & -8.38 & $119.7 \pm 9.6$ & 1972 & 16 & \\
\hline 203 & $2 \operatorname{Dec} 1988$ & 185 & 0.1578 & 19.2 & -6.70 & $116.2 \pm 9.4$ & 1972 & 16 & $24(1964)$ \\
\hline 529 & 12 Jul 1989 & 180 & 0.1465 & 19.1 & -7.84 & $41.2 \pm 9.7$ & 1964 & 25 & $26(1963)$ \\
\hline 552 & 25 Jun 1989 & 180 & 0.1523 & 19.8 & -7.16 & $68.1 \pm 9.2$ & 1966 & 23 & $26(1963)$ \\
\hline 564 & 4 Jul 1989 & 195 & 0.1695 & 18.2 & -7.32 & $78.5 \pm 10.1$ & 1967 & 22 & $29(1960)$ \\
\hline 584 & 9 Jul 1989 & 195 & 0.1851 & 19.5 & -8.42 & $69.6 \pm 8.5$ & 1966 & 23 & \\
\hline 598 & 15 Jul 1989 & 182 & 0.1861 & 12.3 & -7.26 & $75.2 \pm 10.7$ & 1967 & 22 & $27(1962)$ \\
\hline 642 & 29 Jun 1989 & 186 & 0.2353 & 24.4 & -8.18 & $-38.8 \pm 7.1$ & 1958 & 31 & \\
\hline 753 & 16 Jun 1989 & 190 & 0.1863 & 18.6 & -7.26 & $55.2 \pm 9.9$ & 1965 & 24 & \\
\hline 2278 & 24 Feb 1993 & 55 & 0.0135 & 13.8 & 8.53 & $80.0 \pm 8.6$ & 1992 & 1 & \\
\hline 4670 & 11 Nov 1993 & 184 & 0.1550 & 13.1 & -6.59 & $101.0 \pm 11.0$ & 1970 & 23 & $24(1969)$ \\
\hline 4682 & 18 Nov 1993 & 180 & 0.1774 & 15.6 & -6.79 & $88.2 \pm 10.8$ & 1968 & 25 & $23(1970)$ \\
\hline 4693 & 18 Nov 1993 & 185 & 0.1684 & 19.6 & -7.33 & $73.8 \pm 10.4$ & 1967 & 26 & $27(1966)$ \\
\hline 4698 & 14 Nov 1993 & 201 & 0.1719 & 15.8 & -7.58 & $50.1 \pm 9.4$ & 1965 & 28 & \\
\hline 4732 & 18 Apr 1985 & 55 & 0.0140 & 14.2 & -9.51 & $1.15 .1 \pm 9.2$ & 1984 & 1 & \\
\hline 6288 & 6 Nov 1994 & 190 & 0.219 & 16.8 & -6.8 & $71.1 \pm 10.2$ & 1967 & 27 & $30(1964)$ \\
\hline 6289 & $3 \mathrm{Dec} 1994$ & 194 & 0.2046 & 19.8 & -6.8 & $37.2 \pm 11.9$ & 1964 & 30 & $26(1968)$ \\
\hline 6290 & 28 Dec 1994 & 189 & 0.2835 & 19.8 & -7.1 & $85.7 \pm 10.7$ & 1968 & 26 & $28(1966)$ \\
\hline 6291 & 6 Dec 1994 & 196 & 0.2773 & 19.2 & -7 & $-18.1 \pm 8.8$ & 1960 & 34 & $34(1960)$ \\
\hline 6292 & 6 Dec 1994 & 196 & 0.2402 & 19.8 & -7.8 & $73 \pm 8.6$ & 1967 & 27 & $28(1966)$ \\
\hline 6293 & 26 Dec 1994 & 199 & 0.2093 & 19.9 & -7.4 & $54.2 \pm 8.6$ & 1965 & 29 & $29(1965)$ \\
\hline
\end{tabular}

water dissolved inorganic carbon (DIC) and corals, both representative of the year 1953, were not used in the estimation of the function. Radiocarbon data were not available in the relevant area between about 1963 and 1970 . The function determined from these data (Fig. 2) describes a time series of $\Delta^{14} \mathrm{C}$ that is similar to that modelled for $\Delta^{14} \mathrm{C}$ in the southern hemisphere tropical Indian Ocean by Broecker et al. (1985). The resulting function was used to estimate the birth dates of the large southern bluefin tuna on the basis of the $\Delta^{14} \mathrm{C}$ measured in the earliest formed regions of the individual otoliths. $\Delta^{14} \mathrm{C}$ data measured in the sagittae of 22 southern bluefin tuna are plotted with $\Delta^{14} \mathrm{C}$ determined in surface seawater DIC from the GEOSECS expeditions (Bien et al, 1965, Stuiver \& Ostlund 1983) and from known-age segments of hermatypic corals from Cocos-Keeling Island in the Indian Ocean (Toggweiler et al. 1991) (Fig. 3).

Radiocarbon-based estimates of birth dates for the 20 large southern bluefin tuna range from 1958 to 1973 (Table 2). The birth date estimated for the oldest tuna in this study provides an indication of the latest reasonable birth date (i.e. the fish could be older). Because this individual was spawned prior to significant atmospheric testing of nuclear weapons, the portions of the otolith that were analysed do not contain any detectable bomb-derived radiocarbon. Radiocarbon- based birth dates from southern bluefin were also plotted with otolith radiocarbon data obtained from previous studies of snapper Pagrus auratus and redfish

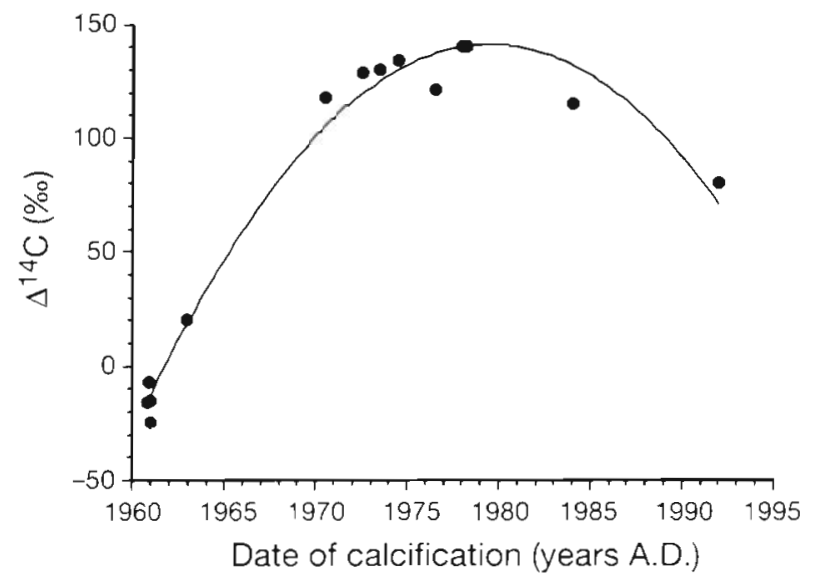

Fig. 2. Data and function used to provide a calibration for Indian Ocean $\Delta^{14} \mathrm{C}$ values dunng the increase in bombderived radiocarbon. Data points prior to 1980 were derived from measurements of dissolved inorganic carbon in surface seawater (Bien et al. 1965, Stuiver \& Ostlund 1983, Toggweiler et al. 1991]. Data points from 1984 and 1992 wnre determined from measurements of radiocarbon in whole otoliths of $1 \mathrm{yr}$ old southern bluefin tuna. The polynomial function is: $\Delta^{14} C=-1759667+1778$ (year) -0.45 (year) $^{2}$ 


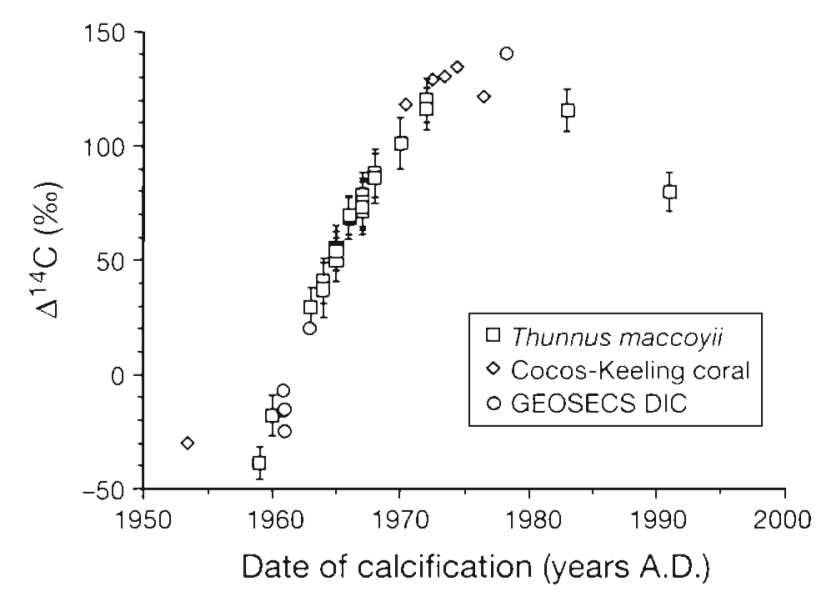

Fig. 3. Radiocarbon data from southern bluefin tuna otoliths, Cocos-Keeling Island hermatypic coral (Toggweiler et al. 1991), and GEOSECS (Geochemical Ocean Section Study) DIC (dissolved inorganic carbon) (Bien et al. 1965, Stuiver \& Ostlund 1983). The date of calcification for the southern bluefin tuna data was determined on the basis of a second order polynomial function described by the post-bomb coral and GEOSECS radiocarbon data, as well as 2 small southern bluefin tuna with birthdates of 1983 and 1991

Centroberyx affinis (Fig. 4). The data from P. auratus describe an established calibration curve for increases in radiocarbon in the temperate South Pacific Ocean off New Zealand (Kalish 1993). The data from C. affinis are based on age estimates derived from the reading of otolith sections combined with radiocarbon analyses and are representative of changes in ocean radiocar-

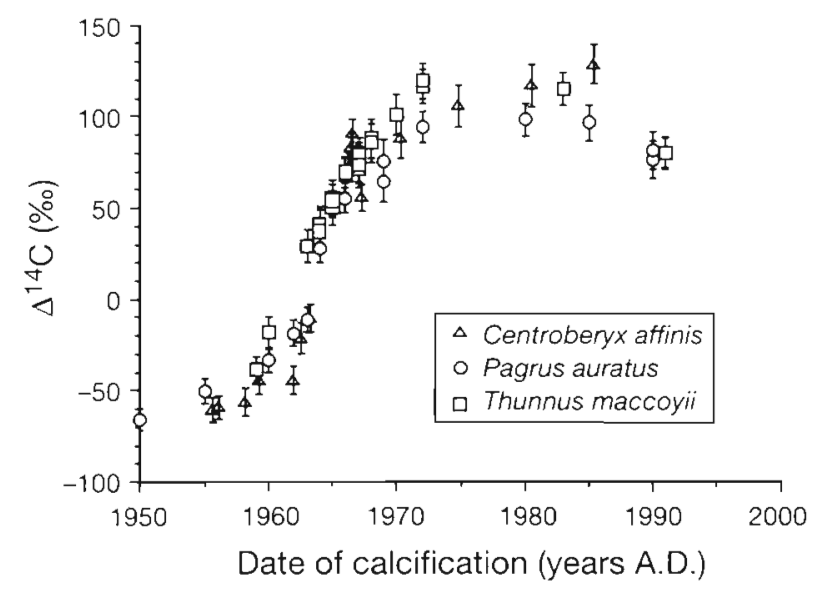

Fig. 4. $\Delta^{14} \mathrm{C}$ of southern bluefin tuna otolith cores plotted against the birth date determined from radiocarbon levels. $\triangle^{14} \mathrm{C}$ data from Pagrus auratus otolith cores are plotted against the true birth date (Kalish 1993) and $\Delta^{14} \mathrm{C}$ values from Centroberyx affins (Kalish 1995b) are plotted against birth dates determined from reading otolith sections. For southern bluefin tuna, $P$. auratus, and $C$. affinis $\Delta^{14} C$ values are based on otolith material deposited over a time period equivalent to about the first year of life. Errors are $\pm 1 \mathrm{SD}$ bon off the east coast of Australia at temperate latitudes (Kalish 1995b). The tuna birth dates and corresponding $\Delta^{14} \mathrm{C}$ values are coincident with both the $P$. auratus and $C$. affinis data until the 1970 s when tuna otolith $\Delta^{14} \mathrm{C}$ reaches higher levels than the data from $P$. auratus. In later years, the tuna data agree more closely with the $C$. affinis data.

Age estimates for southern bluefin tuna were calculated on the basis of the radiocarbon-based birth date estimates and known collection dates for individual fish (Table 2) and were compared with age estimates from the counting of presumed annual increments on transverse sections of otoliths. Because pairs of otoliths were not obtained from all fish, only 15 of the 22 samples analysed for radiocarbon had corresponding otolith sections. An age difference plot, where the difference between the age estimated from the otolith sections and $\Delta^{14} \mathrm{C}$ is plotted as a function of the 'bomb radiocarbon age', was used to compare age estimates (Fig. 5). Pairwise age comparisons between the section and bomb radiocarbon estimates suggest that there may be significant differences between the 2 methods of age estimation (2-tailed $t$-test; $\mathrm{df}=14 ; \mathrm{p}=0.051$ ). If the bomb radiocarbon age estimates are taken as the standard, then there appears to be evidence that section ages of several of the youngest fish may be overestimates for this small sample.

When $\Delta^{14} \mathrm{C}$ measured in southern bluefin otoliths is plotted as a function of the birth dates estimated from the reading of otolith sections, several data points diverge significantly from the bomb radiocarbon curve derived from Pagrus auratus otoliths (Fig. 6). Specifically, 3 southern bluefin section ages (Sample nos. 203, 564 , and 598) fall outside the curves defined by the $95 \%$ confidence limits determined for individual pre-

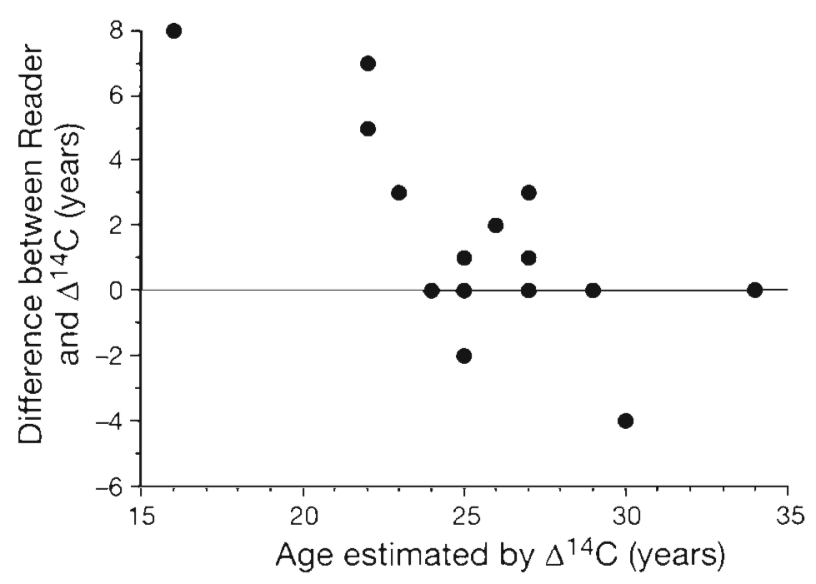

Fig. 5. Thunnus maccoyii. Differences (yr) between age estimates determined from radiocarbon data and reading otolith thin sections 


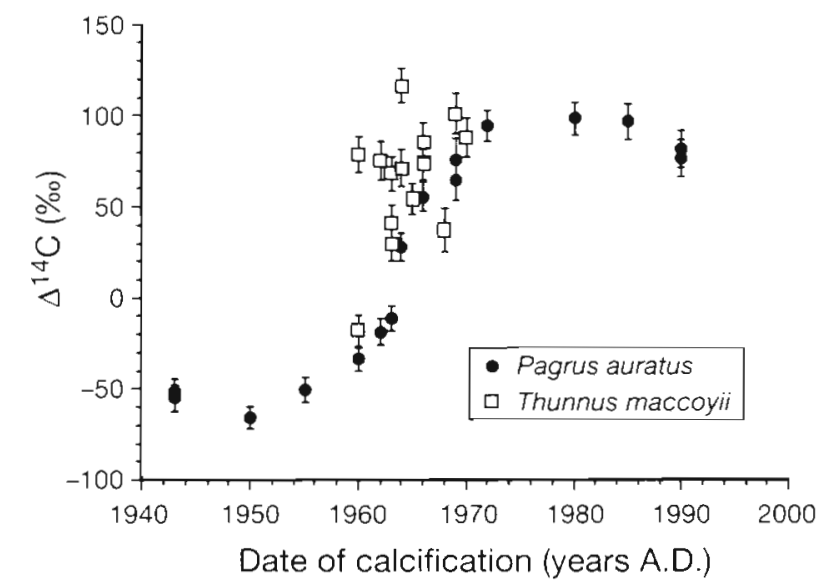

Fig. 6. $\Delta^{14} \mathrm{C}$ values versus birth date estimates for southern bluefin tuna from otolith readers plotted with $\Delta^{14} \mathrm{C}$ data versus birth date data for Pagrus auratus

dicted values from the $P$. auratus radiocarbon and birth date data. The ages (birth dates) of these presumably younger fish, with greater quantities of bomb radiocarbon in their otoliths, appear to be overestimated as they fall to the left of the bomb radiocarbon curve defined by $P$, auratus.

\section{DISCUSSION}

Objective estimates of southern bluefin tuna age are possible on the basis of radiocarbon analyses made in the earliest formed segments of otoliths. The age estimates were based on the assumption that most of the observed variation in otolith $\Delta^{14} \mathrm{C}$ was related to differences in the birth date of individual southern bluefin. The primary support for this assumption is derived from the fact that there were rapid increases in radiocarbon in tropical and temperate oceans during the 1960 s and 1970 s and that otolith radiocarbon is a good proxy of radiocarbon in seawater DIC (Kalish 1993).

Radiocarbon data from selected regions of southern bluefin tuna otoliths indicate that this species can reach ages in excess of $30 \mathrm{yr}$. Furthermore, individuals that approach the asymptotic length $\left(L_{\infty}\right)$ are likely to be 20 yr of age or older The data agree generally with accepted models of southern bluefin tuna growth derived from tagging data and with growth curves based on zone counts in otoliths across the size range of the species (Gunn et al. 1995). A detailed comparison with current growth models was not possible because of the size range of individuals used. The estimates of length at age suggest that the estimate of $L_{\infty}$ is good and, furthermore, that it is not feasible to estimate age from length for southern bluefin tuna greater than about $180 \mathrm{~cm}$ FL.
Peak radiocarbon levels measured in southern bluefin tuna otoliths are higher than those measured in Pagrus auratus otoliths from of the east coast of New Zealand, but similar to those measured in Centroberyx affinis otoliths from the Tasman Sea off southeast Australia. The higher level of radiocarbon in the tuna otoliths was expected on the basis of the relative proximity of the northeastern Indian Ocean and the temperate central South Pacific Ocean to Northern Hemisphere atmospheric testing. Rapid transport of seawater through the Pacific-Indian oceans throughflow region (Fieux et al. 1994) would result in effective transport of radiocarbon from the Pacific to the Indian Ocean and, ultimately, would also result in relatively high radiocarbon levels in the tropical and subtropical Indian Ocean. The ocean off southeast Australia would also be expected to receive greater quantities of bomb derived radiocarbon due to ocean transport via the East Australian Current.

There are several possible sources of error that may affect the strict interpretation of radiocarbon in southern bluefin tuna otoliths in terms of birth dates/age. Firstly, the material isolated for radiocarbon analyses is sculpted from the whole otolith. Incomplete removal of otolith calcium carbonate deposited later in life (i.e. younger otolith material) would affect the level of radiocarbon measured in that sample. For example, many of the tuna otoliths that had relatively high radiocarbon levels $(>50 \%$ ), i.e. relatively young fish, were estimated to be older on the basis of reading otolith sections. If sculpting failed to remove all otolith material deposited after the first year of life for fish spawned in the late 1950 s or 1960 s, then younger otolith material with higher radiocarbon levels would 'contaminate' the sample. This would result in a radiocarbon-based age estimate that was younger than the true value. The majority of discrepancies between section age and bomb radiocarbon age indicate that the-radiocarbon age is younger than the section age. On this basis, contamination of the samples with calcium carbonate deposited after the first year of life and/or a slight bias to overestimate age from otolith sections must be considered as possibilities

The inclusion of younger otolith material in a sample believed to be representative of the first year of growth may occur due to inaccurate sculpting; however, the degree of contamination required to explain the larger age discrepancies observed is not likely. A mass balance model was used to illustrate the effect of different levels of contamination on $\Delta^{14} \mathrm{C}$ for the 2 samples that showed the greatest difference between bomb radiocarbon age and section age. Sample no. 203 was estimated to be $16 \mathrm{yr}$ of age (birth date of 1972) on the basis of $\Delta^{14} \mathrm{C}(116.2 \pm 9.4 \%)$, whereas the otolith section age was $24 \mathrm{yr}$ (birth date of 1964). $\Delta^{14} \mathrm{C}$ in the eastern Indian 
Ocean was estimated to be about $40 \%$ in 1964 (see Fig. 2), well below the value measured in Sample no. 203 (Table 2). If this fish was, in fact, spawned in 1964 and the sample was sculpted without contamination. then we would expect the sample of about $20 \mathrm{mg}$ to have a $\Delta^{14} \mathrm{C}$ of $40 \%$. Consider the possibility that, after sample sculpting is complete, the sample contains $18 \mathrm{mg}$ of material with a $\Delta^{14} \mathrm{C}$ of $40 \%$ and $2 \mathrm{mg}$ of material deposited after the first year of life and with a $\Delta^{14} \mathrm{C}$ of $50 \%$. In this case, the sample would have a $\Delta^{14} \mathrm{C}$ of $40.5 \%$. Assume each additional $2 \mathrm{mg}$ of younger calcium carbonate that replaces $2 \mathrm{mg}$ of calcium carbonate deposited during the first year of life results in a $10 \%$ increase in mean $\Delta^{14} \mathrm{C}$ of the inappropriately included material. Under this scenario, it would be necessary for the sculpted Sample no. 203 to contain $2 \mathrm{mg}$ of calcium carbonate with a $\Delta^{14} \mathrm{C}$ of $40 \%$ deposited during the first year of life and $18 \mathrm{mg}$ with a $\Delta^{14} \mathrm{C}$ of $130 \%$ to obtain a $\Delta^{14} \mathrm{C}$ of $116 \%$ for a southern bluefin spawned in 1964 Given the degree of care taken with the sculpting process this extent of contamination is extremely unlikely. Furthermore, this model overestimates the probable $\Delta^{14} \mathrm{C}$ for the contaminant and it is likely to be much lower in those instances where the sample sculpting process was imprecise. A similar model was applied to the results from Sample no. 564 where bomb radiocarbon and otolith section age estimates differed by 7 yr (Table 2). In order for the correct birthdate to be 1960 $\left(\triangle^{14} \mathrm{C}\right.$ of about $-18 \%$ ) for Sample no. 564 , it would have been necessary for the $18.2 \mathrm{mg}$ sample to contain $15.5 \mathrm{mg}$ of 'contaminant' with a $\Delta^{14} \mathrm{C}$ of about $90 \%$. These arguments assume that, although spatial variation in surface ocean $\triangle^{14} \mathrm{C}$ can be significant over the possible range of $1 \mathrm{yr}$ old southern bluefin (see below), this variation is small when compared with temporal variation in $\Delta^{14} \mathrm{C}$ during the 1960 s and early 1970 s. The relatively small variation in $\Delta^{14} \mathrm{C}$ over large (primarily meridional) spatial scales is evident in Fig. 4 where data derived from the east coasts of New Zealand (Pagrus auratus) and New South Wales (Centroberyx affinis) and the eastern Indian Ocean are compared.

The likelihood of sample contamination by otolith material deposited later in life could be reduced by sculpting smaller samples. In this study, otolith sample weights for radiocarbon analyses were maintained between 13.1 and $24.4 \mathrm{mg}$ (1.6 to $2.9 \mathrm{mg}$ of carbon) based on the requirement for a minimum quantity of carbon to achieve a specified level of analytical precision at the AMS facility that did the analyses. Analysis of radiocarbon by AMS has developed to the point where it is possible, at some facilities, to obtain high precision analyses on samples that contain less than $0.5 \mathrm{mg}$ of carbon ( $4 \mathrm{mg}$ of $\mathrm{CaCO}_{3}$ ). Because the ability to analyse small samples varies among laboratories, it is important to consult with the operators of AMS facilities be- fore submitting samples for radiocarbon analysis. It is recommended that the smallest sample size that can be analyzed with high precision $(< \pm 10 \%)$ be used for AMS analysis in those cases where the species under investigation has relatively small otoliths.

Southern bluefin tuna is a highly migratory species and appears to travel great distances during the first year of life (Shingu 1978, CSIRO unpubl. data). The exact nature of these movements is not well defined and some individuals appear to migrate south along the western coast of Australia, whereas other young southern bluefin may move in a southwesterly direction towards the coast of South Africa. Data on southern bluefin movements indicate that 1 yr old fish can move significant distances from the spawning grounds in the tropical Indian Ocean south of Java, between about $10^{\circ} \mathrm{S}$ and $15^{\circ} \mathrm{S}$ latitude. Southern bluefin $25 \mathrm{~cm}$ FL (90 to 120 d old) have been collected between Northwest Cape and Freemantle, Western Australia and fish between 50 and $55 \mathrm{~cm} \mathrm{FL} \mathrm{(1} \mathrm{yr} \mathrm{old)} \mathrm{have} \mathrm{been}$ captured off New South Wales, Tasmania, Victoria, South Australia, Western Australia and South Africa (CSIRO unpubl. data). These movements would expose individual southern bluefin to varying levels of radiocarbon while the earliest formed portions of the otolith were being deposited. In addition, the rapid increase in ocean radiocarbon levels between about 1960 and 1975 would expose individual fish to temporally varying radiocarbon.

Radiocarbon data in Stuiver \& Ostlund (1983) show significant latitudinal and longitudinal variation during the 1977-1978 Indian Ocean GEOSECS expedition. These data can be used as a basis for understanding the distribution of bomb radiocarbon in earlier years. The highest concentration of bomb radiocarbon was found in the central gyre of the Indian Ocean between about $10^{\circ} \mathrm{S}$ and $35^{\circ} \mathrm{S}$. In the eastern section of the gyre, $\Delta^{14} \mathrm{C}$ values were up to about $140 \%$, but were slightly lower in the western portion of the gyre. Far greater variation in $\Delta^{14} \mathrm{C}$ values was found with latitude. In 1977-1978, maximum $\Delta^{14} \mathrm{C}$ values of around $140 \%$ in southern tropical latitudes of the Indian Ocean decreased to about $28 \%$ (eastern Indian Ocean) and $-14 \%$ (western Indian Ocean) at around $50^{\circ} \mathrm{S}$ latitude, the southern extent of the range of adult southern bluefin. The range of $\Delta^{14} \mathrm{C}$ values was much less at the southernmost extent of the distribution of $1 \mathrm{yr}$ old southern bluefin at around $35^{\circ} \mathrm{S}$ latitude. In 1977-1978, $\Delta^{14} \mathrm{C}$ levels were about $98 \%$ at $35^{\circ} \mathrm{S}$ latitude in both the eastern and western Indian Ocean.

As juvenile southern bluefin migrate south or southwest from the tropical Indian Ocean the growing otolith will integrate radiocarbon levels over a broad temporal (months) and spatial (1000s of km) scales. Because both the path taken by individual tuna and the 
temporal and spatial variation in surface ocean radiocarbon will vary over time, individual otoliths will incorporate different levels of radiocarbon regardless of the birth date of individual fish. The effect of this variation can be reduced by sculpting smaller otolith samples for radiocarbon analysis, thereby limiting the range of possible movements by young fish as they move from the spawning grounds.

Fish species incorporate different levels of carbon isotopes into the $\mathrm{CaCO}_{3}$ of the otoliths and these differences may be linked to metabolic rate effects (Kalish 1991). Southern bluefin tuna otoliths have been shown to be relatively depleted in ${ }^{13} \mathrm{C}$ compared with otoliths from other non-scrombrid fish. This fractionation of carbon isotopes in the otoliths is likely to be reflected in the incorporation of ${ }^{14} \mathrm{C}$; however, these effects were considered in this study, as the calculation of $\Delta^{14} \mathrm{C}$ accounts for fractionation (Stuiver \& Polach 1977).

Southern bluefin tuna otoliths for this study were selected at random from large fish sampled by CSIRO researchers and collaborators. The sample is not adequate to estimate the range of ages present in the population of southern bluefin tuna, but it does suggest that a large percentage of the fish greater than $180 \mathrm{~cm}$ FL are at least $20 \mathrm{yr}$ of age and that southern bluefin can live to ages in excess of $30 \mathrm{yr}$ Furthermore, the results show that reading otolith sections is an effective method to estimate the age of larger southern bluefin. The analysis of additional samples could provide data relevant to defining the age structure of larger southern bluefin tuna and more precisely define the accuracy of age estimation by the reading of otolith sections.

Acknowledgements. We thank the numerous observers who have worked at sea on longline vessels to collect samples from southern bluefin tuna. This research was supported by a grant from the Fisheries Research and Development Corporation.

\section{LITERATURE CITED}

Anonymous (1994) Report of the thirteenth meeting of Australian, Japanese and New Zealand scientists on southern bluefin tuna, Wellington. New Zealand. Commission for the Conservation of Southern Bluefin Tuna

Bien GS, Rakestraw NW, Suess I JE (1965) Radiocarbon in the Pacific and Indian oceans and its relation to deep water movements. Limnol Oceanogr 10(5):R25-R37

Broecker WS, Peng TH, Ostlund G. Stuiver M (1985) The distribution of bomb radrocarbon in the ocean. $J$ Geophys Res 90(C4):6953-6970

Caton A, McLoughlin K, Willaams MJ (1990) Southern bluefin tuna. Bureau of Rural Resources, Austraha, Bulletin No. 3

Collette BB, Nauen CE (1983) Scombrids of the world. FAO Species Catalogue Vol 2, FAO, Rome

Fieux $M$, Andrié C. Delecluse P, llahıde AG, Kartavtseff A, Mantisi F, Molcard R, Swallow JC (1994) Measurements within the Pacific-Indian oceans throughflow region. Deep Sea Res 41:1091-1130

Gunn JS, Clear NP, Carter TI, Rees AJ, Stamley CA, Kalish
JM. Johnston JM (1995) Age and growth of southern bluefin tuna, 1995 report on research. Commission for the Conservation of Southern Bluefın Tuna 1 Scientific Meeting, Shimizu, Japan, SBFWS/95/8

Hurley PCF, Iles TD (1983) Age and growth estimation of Atlantic bluefin tuna, Thunnus thynnus, using otoliths. In: Prince ED, Pulos LM (eds) Proceedings of the international workshop on age determination of orranic pelagic fishes: tunas, billfishes, and sharks. NOAA Tech Rep NMFS 8, p 71-75

Kailola PJ, Williams MJ, Stewart PC, Reichelt RE, MCNee A, Grieve C (1993) Australian fisheries resources. Bureau of Resource Sciences and the Fisheries Research and Development Corporation, Canberra, Australia

Kalish JM $(1991){ }^{13} \mathrm{C}$ and ${ }^{18} \mathrm{O}$ isotopic disequilibria in fish otoliths: metabolic and kinetic effects. Mar Ecol Prog Ser 75:191-203

Kalish JM (1993) Pre- and post-bomb radiocarbon in fish otoliths. Earth Planet Sci Lett 114:549-554

Kalish JM (1995a) Radiocarbon and fish biology. In: Secor DH Dean JM, Campana SE (eds) Recent developments in fish otolith research. University of South Carolina Press, Columbia, p $637-653$

Kalish JM (1995b) Application of the bomb radiocarbon chronometer to the validation of redfish Centroberyx affinis age. Can J Fish Aquat Sci 52:1399-1405

Kalish JM, Beamish RJ, Brothers EB, Casselman JM, Francis RICC, Mosegaard H, Panfili J, Prince ED, Thresher RE, Wilson CA, Wright PJ (1995) Glossary for otolith studies. In: Secor DH, Dean JM, Campana SE (eds) Recent developments in fish otolith research. University of South Carolina Press, Columbia, p 723-729

Lee DW, Prince ED (1995) Analysis of otoliths and vertebrae from nine tag-recaptured Atlantic bluefin tuna (Thunnus thynnus). In: Secor DH, Dean JM, Campana SE (eds) Recent developments in fish otolith research. University of South Carolina Press, Columbia, p 361-374

Lowe DC, Judd WJ (1987) Graphite target preparation for radiocarbon dating by accelerator mass spectrometry. Nucl Instr Meth Phys Res B 28:113-116

Majkowski J, Hampton J (1983) Deterministic partitioning of the catch of southern bluefin tuna, Thunnus maccoyn, into age classes using an age-length relationship. In: Prince ED, Pulos LM (eds) Proceedings of the international workshop on age determination of oceanic pelagic fishes: tunas. billfishes, and sharks. NOAA. Tech Rep NMFS 8, p 87-90

Prince ED. Lee DW, Javech JC (1985) Internal zonation in sections of vertebrae from Atlantic bluefin tuna. Thunnus thynnus, and their potential use in age determination. Can $J$ Fish Aquat Sci 42:938-946

Prince ED. Pulos LM (eds) (1983) Proceedings of the international workshop on age determination of oceanic pelagic fishes: tunas, billfishes, and sharks. NOAA Tech Rep NMFS 8

Shingu $C$ (1978) Ecology and stock of southern bluefin tuna. CSIRO Division of Fisheries and Oceanography Rep no. 131

Stuiver M. Ostlund HG (1983) GEOSECS Indian Ocean and Mediterranean radiocarbon. Radiocarbon 25:1-29

Stuiver M, Polach H (1977) Reporting of ${ }^{14} \mathrm{C}$ data. Radiocarbon 19:355-363

Thorogood J (1987) Age and growth determination of southern bluefin tuna, Thunnus maccoyid, using otolith banding. J Fish Biol 30:7-14

Toggweiler JR, Dixon K, Broecker WS (1991) The Peru upwelling and ventilation of the South Pacific thermocline. $J$ Geophys Res 96:20467-20496

Wallace G, Sparks RJ, Lowe DC, Pohl KP (1987) The New Zealand accelerator mass spectrometry facility. Nucl Instr Meth B29:124-128 